\title{
Somatomedin activity in synovial fluid from patients with joint diseases
}

\author{
CLAIRE L. COATES, R. GEOFFREY BURWELL, K. LLOYD-JONES, \\ A. J. SWANNELL, G. WALKER, AND C. SELBY
}

From the Department of Human Morphology, Medical School, University of Nottingham; Department of Rheumatology, Harlow Wood Orthopaedic Hospital, Mansfield, Nottinghamshire; Department of Rheumatology, City Hospital, Nottingham; Department of Chemical Pathology, General Hospital, Nottingham; Department of Clinical Chemistry, City Hospital, Nottingham

SUMMARY The somatomedin activity in synovial fluids from 50 patients with a variety of joint diseases has been studied and compared with the activity in each of the patient's own serum and a standard reference serum (SRS). The porcine costal cartilage bioassay of Van den Brande and Du Caju (1974a) has been used with the isotopes ${ }^{3} \mathrm{H}$-thymidine and ${ }^{35} \mathrm{~S}$-sulphate. Synovial fluids from most patients with post-traumatic and post-operative effusions, osteoarthritis and arthritis associated with psoriasis, Reiter's disease, and ankylosing spondylitis stimulated the synthesis of DNA and proteoglycans in cartilage. Synovial fluids from patients with rheumatoid arthritis either had impaired capacity to stimulate DNA synthesis, or they inhibited it; a similar, but less evident pattern was observed for proteoglycan synthesis. Some synovial fluids from patients with miscellaneous synovitides stimulated, while others inhibited cartilage metabolism. It is concluded that the synovial fluid from patients with rheumatoid arthritis and from some patients with miscellaneous synovitides contained an inhibitor(s) to DNA and possibly proteoglycan synthesis.

The sera from nearly all the patients stimulated both DNA and proteoglycan synthesis, but the somatomedin potency ratios for serum in terms of SRS were generally less than $1 \cdot 0$. There was a significant inverse correlation between the serum somatomedin potency ratio and the age of the patient.

We have previously reported that the somatomedin activity in normal synovial fluid from the knee joint of the ox is lower than that in serum from the same animal; and that the somatomedin activity is related to the total protein and albumin concentrations (Coates et al., 1977).

This paper examines the somatomedin activity in synovial fluid from patients with joint diseases and compares it with the activity in each of the patient's own serum and in a standard reference serum (SRS). The porcine costal cartilage bioassay of Van den Brande and Du Caju (1974a) was used, with the isotopes ${ }^{3} \mathrm{H}$-thymidine (DNA synthesis) and ${ }^{35} \mathrm{~S}$ sulphate (proteoglycan synthesis). This bioassay measures the net effect of all stimulants and inhibitors that are capable of influencing the uptake of ${ }^{3} \mathrm{H}$ -

Accepted for publication November 2, 1977

Correspondence to Professor R. G. Burwell, Department of Human Morphology, University Hospital and Medical School, Nottingham. thymidine or ${ }^{35} \mathrm{~S}$-sulphate into cartilage. Somatomedin(s) is a stimulant of such metabolism.

Since a preparation of purified somatomedin is not available for routine use, a pool of normal human serum was used as the somatomedin standard. This was termed the standard reference serum (SRS) and was included in every assay. The dose response lines for the SRS and the test fluids were compared and for a valid somatomedin assay they must have a significant regression and be parallel. A significant regression indicates that the isotopic uptake increased with increasing concentrations of the fluids and hence the fluids contained a net stimulant(s) to cartilage metabolism. Parallelism between the standard and test fluids indicates that isotopic uptake increased by proportionately the same amount with increasing concentrations of each fluid. In this case it is generally considered that somatomedin(s) produced the response in each fluid. When dose response curves for the standard and the test 
fluids are not parallel, then factors other than somatomedins are generally considered to be influencing the result. When a fluid gave a dose response line with a significant negative regression, isotopic uptake decreased with increasing concentrations of the fluid. This indicates the presence in that fluid of an inhibitor(s) to the uptake and/or the incorporation of the isotope.

\section{Materials and methods}

\section{SAMPLE COLLECTION AND PREPARATION}

Synovial fluid and blood samples were obtained from 50 patients with a variety of disorders and diseases as shown in Table 1. Using the criteria of the American Rheumatism Association, all the patients in group 2 had 'classical' rheumatoid arthritis (Ropes et al., 1959). Samples were obtained from patients with post-traumatic and post-operative effusions at arthroscopy for internal derangement of the knee (3) or after surgery for torn menisci (4), patellectomy for chondromalacia patellae (2) or lateral release at the knee (1). One fluid was obtained from a patient with a haemorrhagic effusion associated with pathological fracture of the tibial plateau.

The synovial fluid and blood samples were taken at the same time and collected into plain glass bottles. Both samples were incubated at $37^{\circ} \mathrm{C}$ for 1 hour and then left in the refrigerator overnight.

\section{Table 1 The patients}

\begin{tabular}{|c|c|c|c|c|}
\hline \multirow[t]{2}{*}{ Diagnosis } & \multirow{2}{*}{$\begin{array}{l}\text { No. of } \\
\text { patients }\end{array}$} & \multicolumn{2}{|l|}{$\operatorname{Sex}$} & \multirow{2}{*}{$\begin{array}{l}\text { Mean } \\
\text { age in } \\
\text { years } \\
\text { (and } \\
\text { range) }\end{array}$} \\
\hline & & Male & Female & \\
\hline $\begin{array}{l}\text { 1) Post-traumatic and post- } \\
\text { operative effusions }\end{array}$ & 11 & 9 & 2 & $\begin{array}{l}29 \\
(16-60)\end{array}$ \\
\hline 2) Rheumatoid arthritis & 16 & 2 & 14 & $\begin{array}{l}57 \\
(32-75)\end{array}$ \\
\hline 3) Osteoarthritis & 4 & 1 & 3 & $\begin{array}{l}64 \\
(52-86)\end{array}$ \\
\hline $\begin{array}{l}\text { 4) Seronegative spondarthritis } \\
\text { Arthritis associated with:- } \\
\text { Psoriasis }\end{array}$ & 6 & 5 & 1 & 26 \\
\hline Ankylosing spondylitis & 3 & 2 & 1 & $\begin{array}{l}40 \\
(31-50)\end{array}$ \\
\hline Reiter's disease & 1 & 1 & $\mathbf{0}$ & 27 \\
\hline $\begin{array}{l}\text { 5) Juvenile rheumatoid arthritis } \\
\text { ๑) Miscellaneous synovitides } \\
\text { (all seronegative) } \\
\text { Monoarthritis ('probable' }\end{array}$ & 1 & 0 & 1 & 25 \\
\hline RA) & 1 & 1 & 0 & 21 \\
\hline Oligoarthritis & 2 & 1 & 1 & $\begin{array}{l}40 \\
(38-43)\end{array}$ \\
\hline Polyarthritis-asymmetrical & 3 & 2 & 1 & $\begin{array}{l}53 \\
(41-59)\end{array}$ \\
\hline Intermittent arthritis & 1 & 1 & $\mathbf{0}$ & 56 \\
\hline Post-Salmonella arthritis & 1 & 1 & 0 & 27 \\
\hline
\end{tabular}

Serum was withdrawn from the clotted blood an $\frac{\bar{\top}}{\mathrm{T}}$ centrifuged at $500 \mathrm{~g}$ for $20 \mathrm{~min}$. The synovial flui samples were also spun at $500 \mathrm{~g}$ for $20 \mathrm{~min}$. The clear supernatants were retained and stored a $-20^{\circ} \mathrm{C}$ until assayed.

Samples of synovial fluid from the patients with arthritic joints were collected into tubes containing EDTA (ethylenediaminetetra-acetic acid) for tota and differential cell counts.

The erythrocyte sedimentation rate was obtaine $\$$ from a blood sample taken within 1 month of the aspiration of the arthritic joint.

The human standard reference serum (SRS) consisted of pooled sera from 21 normal adults (age range 18 to 48 years). It had been dispensed in aliquots an $\bar{\phi}$ stored at $-20^{\circ} \mathrm{C}$. The standard reference serum wasu included in every assay.

\section{ANALYSES}

\section{Somatomedin bioassay}

The bioassay procedure has previously been reporte (Coates et al., 1977). The method was modified b serially diluting the test fluids by $40 \%$ to $1 \cdot 2 \%$ in Krebs phosphosaline enriched with amino acids ( $a \vec{b}$ the concentration in normal human plasma), glucesse $(1 \mathrm{mg} / \mathrm{ml}$ ), Hepes buffer (to give a final concentratipe of $20 \mathrm{mmol} / \mathrm{l}$ ), and gentamycin (to give a concentration of $20 \mathrm{IU} / \mathrm{ml}$ ).

Inorganic sulphate estimations were performed oक 26 sera and synovial fluids as previously reportec The uptake of ${ }^{35} \mathrm{~S}$-sulphate was corrected for the variations in specific activity of the isotope in the $20 \%$ and $40 \%$ concentrations of each fluid. If inorganic sulphate estimations had not bee performed on a fluid, the isotopic uptake was. corrected using the mean inorganic sulphate con centration for the sera or the synovial fluids that had been analysed. Since the diluent contained approx mately three times as much inorganic sulphate as the fluids, normal variations in the inorganic sulphate concentrations in the sera and synovias fluids had little effect on the final inorganic sulphate concentration in any of the dilutions.

The methods for statistical analysis and totaf protein and albumin estimations have previouslos been described. Any assay with lambda (mean standard deviation of the response/combined slopeo $>0.5$ was rejected. Albumin estimations werg performed using anti-human serum albumixk (Behringwerke).

Duplicate assays were performed at different time on 12 of the synovial fluids. Synovial fluid was aspirated from 2 patients on 2 occasions at intervals of 4 or 5 months. 
EVALUATION OF INHIBITORS IN SYNOVIAL FLUID

\section{Effect of mixing synovial fluid and SRS}

Somatomedin inhibitory activity in synovial fluid was estimated by the ability of the synovial fluid to decrease the SRS-stimulated synthesis of DNA and proteoglycans in cartilage. Synovial fluids (SF) from 1 patient each with psoriasis, Reiter's disease, rheumatoid arthritis, and seronegative oligoarthritis were added to SRS to give mixtures containing $25 \%$, $50 \%$, and $75 \%$ synovial fluid. These mixtures were diluted in the usual way and their somatomedin activities compared with the somatomedin activity in SRS.

Evaluation of the influence of hyaluronic acid on the somatomedin activity in normal serum

Normal human serum was supplemented with $0 \cdot 25$, $0.5,1.0,2.0$, and $4.0 \mathrm{mg} / \mathrm{ml}$ hyaluronic acid (Sigma Ltd) and the somatomedin activity in the serum plus hyaluronic acid was compared with the activity in the serum alone. The experiment was repeated 3 times using serum from a single adult taken on 2 separate occasions.

\section{Results}

\section{SOMATOMEDIN BIOASSAY-SERA}

\section{${ }^{3} \mathrm{H}$-thymidine incorporation}

The patients' sera all gave dose response curves that were parallel with the SRS (Figs. 1 and 2). There was no significant difference between the potency ratios of the patient's serum in terms of the SRS (serum/ SRS) for the 6 groups of disorders examined. The mean potency ratio of serum/SRS for the 50 patients was 0.64 (range 0.21 to $1 \cdot 21$ ) with a mean $\lambda$ of 0.17 (range 0.08 to 0.27 ).

There was a significant inverse correlation between the serum somatomedin potency ratio and the age of the patient $(r=0.31,0.01<P<0.05)$; but there was no significant correlation between the serum somatomedin potency ratio and the duration of arthritis.

\section{${ }^{35} \mathrm{~S}$-sulphate incorporation}

The patients' sera gave, in general, dose response curves that were parallel with the SRS. Five assays were rejected because of non-parallelism, and a further 10 because of an insignificant regression or $\lambda>0 \cdot 5$. There was no significant difference between the serum somatomedin potency ratios for the 6 groups of disorders. The mean potency ratio of serum in terms of SRS was 0.42 (range 0.10 to 1.91 ) with a mean $\lambda$ of 0.34 (range 0.19 to 0.47 ).
The gradient of the dose response obtained when monitoring ${ }^{35} \mathrm{~S}$-sulphate incorporation was consistently less than that obtained with ${ }^{3} \mathrm{H}$-thymidine. The assay results were therefore less accurate and the $\lambda$, as an index of precision, was higher.

There was a significant inverse correlation between the serum somatomedin potency ratio and the age of the patient $(\mathrm{r}=0.44,0.001<\mathrm{P}<0.01)$; but no correlation between the serum somatomedin potency ration and the duration of arthritis.

SOMATOMEDIN BIOASSAY-SYNOVIAL FLUIDS

\section{${ }^{3} \mathrm{H}$-thymidine incorporation}

The synovial fluids always evoked less isotopic uptake than either the patient's own serum or the SRS. The dose response curves for the synovial fluids were not always parallel with those for the sera, indicating that a factor(s) other than somatomedin(s) was influencing the result.

\section{Valid somatomedin assays}

For these the dose response lines for the sera and the synovial fluids were parallel, had a significant regression, and $\lambda<0.5$. They were obtained with synovial fluids from most patients with posttraumatic and post-operative effusions, osteoarthritis and arthritis associated with psoriasis, Reiter's disease, and ankylosing spondylitis (Fig. 1, Table 2). They were also evoked by synovial fluids from the 1 patient with juvenile rheumatoid arthritis, from 1 patient with asymmetrical, seronegative polyarthritis, and from the 1 patient with post-Salmonella arthritis.

For these valid somatomedin assays the mean potency ratio of synovial fluid in terms of the patient's own serum was 0.34 (range 0.07 to 0.78 ) with a mean $\lambda$ of 0.19 (range 0.07 to 0.27 ), values which are consistent with those previously reported for ox fluids (Coates et al., 1977).

Assays were repeated on 3 of these fluids on different occasions and valid somatomedin assays

Table 2 Somatomedin bioassay results for synovial fluids related to the diagnosis

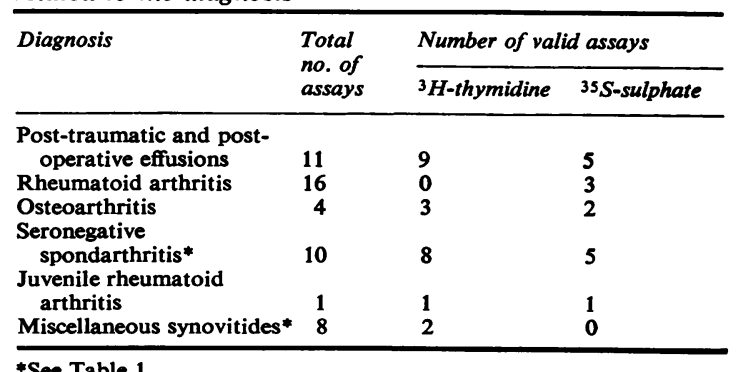




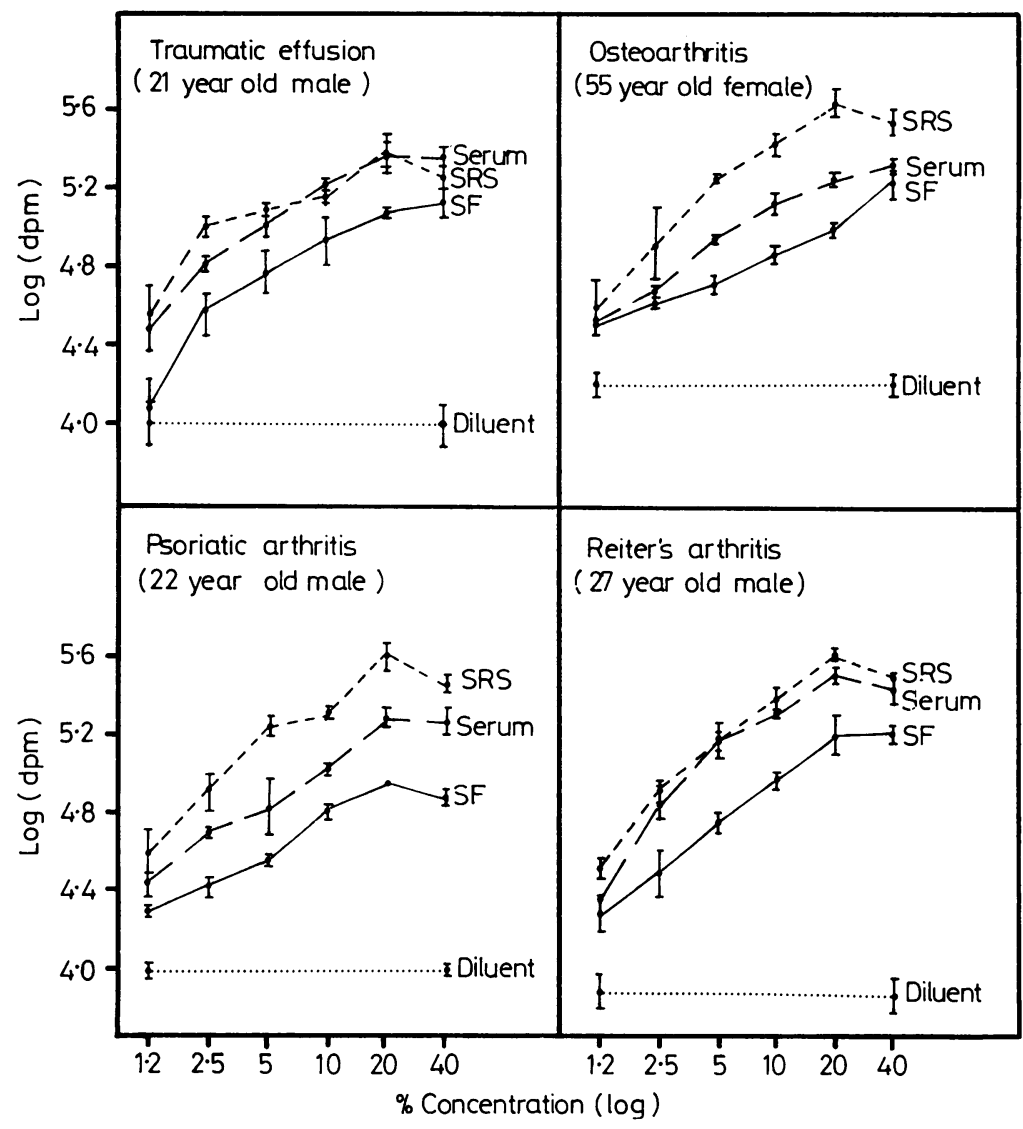

Fig. 1 Valid somatomedin assays. The uptake of ${ }^{3} \mathrm{H}$-thymidine (log dpm) into porcine costal cartilage as a function of the log of the concentration of the $S R S$ and the patients' fluids as shown. (SRS = standard reference serum; $S F=$ patient'ssynovial fluid; $\log =$ logarithm; $\mathbf{d p m}=$ disintegration per minute.)

were obtained each time. Synovial fluid from 1 patient with ankylosing spondylitis was aspirated on 2 occasions, 5 months apart, and each synovial fluid sample gave a valid somatomedin assay.

\section{Invalid somatomedin assays}

These assays were all invalid due to lack of parallelism between the synovial fluid and the patient's serum and the SRS.

The dose response curves for 9 synovial fluids were not parallel with those for the sera, but did have a significant regression (Fig. 2A). This response was obtained with synovial fluids from 1 patient with a post-operative effusion, osteoarthritis and seronegative oligoarthritis, from 2 patients with ankylosing spondylitis, and from 4 patients with rheumatoid arthritis.

Sixteen synovial fluids, all from patients with rheumatoid arthritis or miscellaneous synovitides, gave dose response curves that had either an insignificant regression (Fig. 2B) or a significant negative regression (Fig. 2C). Ten synovial fluids from patients with rheumatoid arthritis evoked decreasing isotopic uptake with increasing concentration. At the higher concentrations, 9 of these fluids induced less isotopic uptake than the diluent (amino acids in Krebs phosphosaline buffer) (Fig. 2C).

Two synovial fluids gave dose response curves that were parallel with the patient's serum and the SRS over the lower concentrations, but exhibited a significant negative regression over the higher concentrations (Fig. 2D). One of these fluids was taken after a patellectomy for chondromalacia patellae, and the other was from a 21 year old man who had 'probable' rheumatoid arthritis of 4 months' duration in one knee.

Nine synovial fluids giving invalid somatomedin assays, were retested at a later date and gave results consistent with those obtained for the first assay. Of these, 2 fluids gave dose response curves with a significant positive regression; 2 gave an insignificant regression, and 5 gave a significant negative regression. Two synovial fluid samples 


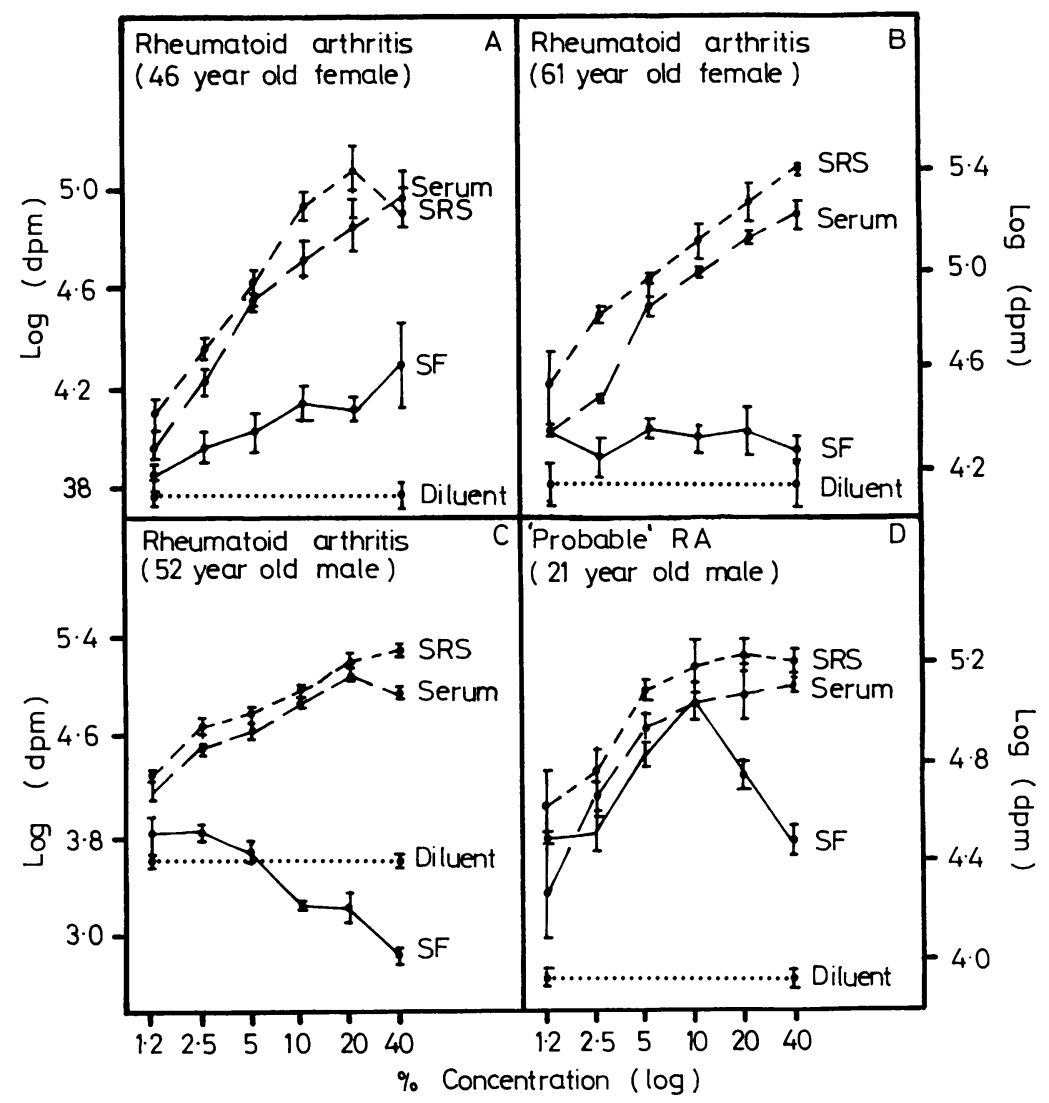

Fig. 2 Invalid somatomedin assays for synovial fluids from patients with rheumatoid arthritis and 'probable' rheumatoid arthritis $(R A)$.

aspirated 4 months apart were assayed from a patient with seronegative oligoarthritis. The first synovial fluid sample gave a dose response curve with a significant negative regression while the second had an insignificant regression.

\section{${ }^{35} S$-sulphate incorporation}

As for ${ }^{3} \mathrm{H}$-thymidine incorporation, not all the synovial fluids gave valid somatomedin assays (Table 2).

Valid somatomedin assays were obtained for 16 synovial fluids. The mean potency ratio for synovial fluid in terms of the patient's own serum was 0.22 (range 0.07 to 0.63 ) with a mean $\lambda$ of 0.33 (range $0 \cdot 22$ to $0 \cdot 46$ ). These values are again consistent with those obtained in the ox.

\section{Invalid somatomedin assays}

Fifteen assays were rejected due to $\lambda>0.5$ or an insignificant regression for the sera. Three synovial fluids gave dose response curves which had a significant regression but were not parallel with those for the sera. These were from 2 patients with post-operative effusions and from 1 patient with psoriatic arthritis. Fourteen synovial fluids gave dose response curves with an insignificant regression. These were from 1 patient with osteoarthritis, 2 patients with ankylosing spondylitis, 3 patients with miscellaneous synovitides, and 8 patients with rheumatoid arthritis. Two synovial fluids gave dose response curves with a significant negative regression. These were from 1 patient with rheumatoid arthritis and from 1 patient with asymmetrical seronegative polyarthritis.

INORGANIC SULPHATE ESTIMATIONS

The mean inorganic sulphate concentration of 26 sera was $37.4 \mu \mathrm{g} / \mathrm{ml}(1 \cdot 19 \mathrm{mmol} / \mathrm{l})$ (range 20 to $90 \mu \mathrm{g} / \mathrm{ml} ; 0.64$ to $2.87 \mathrm{mmol} / \mathrm{l})$ while the mean inorganic sulphate concentration of 26 synovial fluids was $43.5 \mu \mathrm{g} / \mathrm{ml}(1.39 \mathrm{mmol} / \mathrm{l}$ ) (range 26 to 
$102 \mu \mathrm{g} / \mathrm{ml} ; 0.83$ to $3.25 \mathrm{mmol} / \mathrm{l})$. The concentration in the synovial fluid was significantly higher than in the sera $(P<0.001)$.

\section{PROTEIN ESTIMATIONS}

The serum protein concentrations were similar in patients from all the groups of disorders (Table 3). The total protein, albumin, and globulin concentrations were all lower in the patients' synovial fluids than in the sera, but were all higher than the values reported for normal human synovial fluid (Dittmer, 1961). The total protein, albumin, and globulin concentrations were similar for synovial fluids giving valid and invalid somatomedin assays and for all the groups of disorders examined.

Combining the valid somatomedin assays for serum and synovial fluid each in terms of SRS there was a significant correlation between the somatomedin potency ratio obtained with ${ }^{3} \mathrm{H}$-thymidine and the total protein $(\mathrm{r}=0.53, \mathrm{P}<0.001)$, albumin $(r=0.41,0.001<P<0.01)$, and globulin $(r=0.38$, $0.001<\mathrm{P}<0.01)$ concentrations in the fluids. For ${ }^{35} \mathrm{~S}$-sulphate incorporation there was a significant correlation between the somatomedin potency ratio for the patient's serum and synovial fluid each in terms of SRS and the total protein $(r=0.45$, $0.001<\mathrm{P}<0.01)$ and the albumin $(\mathrm{r}=0.42$, $0.001<\mathrm{P}<0.01)$ concentrations in the fluids, but not for the globulin concentrations $(\mathrm{r}=0.30$, $0.05<\mathrm{P}<0 \cdot 10$ ).
There was no significant correlation between the somatomedin potency ratio (using either ${ }^{3} \mathrm{H}-$ thymidine or ${ }^{35} \mathrm{~S}$-sulphate) of synovial fluid in terms of the patient's own serum and the ratio of total protein, albumin, or globulin in the two fluids.

TOTAL AND DIFFERENTIAL CELL COUNTS There was no significant difference between the $\frac{\bar{\sigma}}{\overline{\frac{D}{0}}}$ number of total leucocytes or neutrophils in the $\frac{\vec{\sigma}}{\sigma}$ synovial fluid from the patients with rheumatoid $\varrho$ arthritis, seronegative spondarthritis, and miscel-es laneous synovitides (Table 4). The number of $\vec{\circ}$ lymphocytes, however, was significantly lower in the synovial fluid from the patients with miscellaneous $\vec{\omega}$ synovitides than from the patients with rheumatoid arthritis $(0.001<P<0.05)$ and with seronegative spondarthritis $(0.01<\mathrm{P}<0.05)$.

There was no significant difference between the numbers of total leucocytes, neutrophils, or lym- $\omega$ phocytes in the synovial fluids giving valid and invalid $\omega$ somatomedin assays.

\section{ERYTHROCYTE SEDIMENTATION RATES (ESR)} There was no significant correlation between theo ESR and the serum somatomedin potency ration (using either ${ }^{3} \mathrm{H}$-thymidine or ${ }^{35} \mathrm{~S}$-sulphate).

The patients whose synovial fluids gave vagid $\stackrel{\oplus}{\sim}$ somatomedin assays had significantly lower ESKs. than those whose fluids gave invalid somatomedin assays $\left(\mathrm{P}<0.001\right.$ for ${ }^{3} \mathrm{H}$-thymidine and $0.01<\mathrm{P}$ 0.05 for ${ }^{35} \mathrm{~S}$-sulphate incorporation).

Table 3 Protein concentrations related to the diagnosis

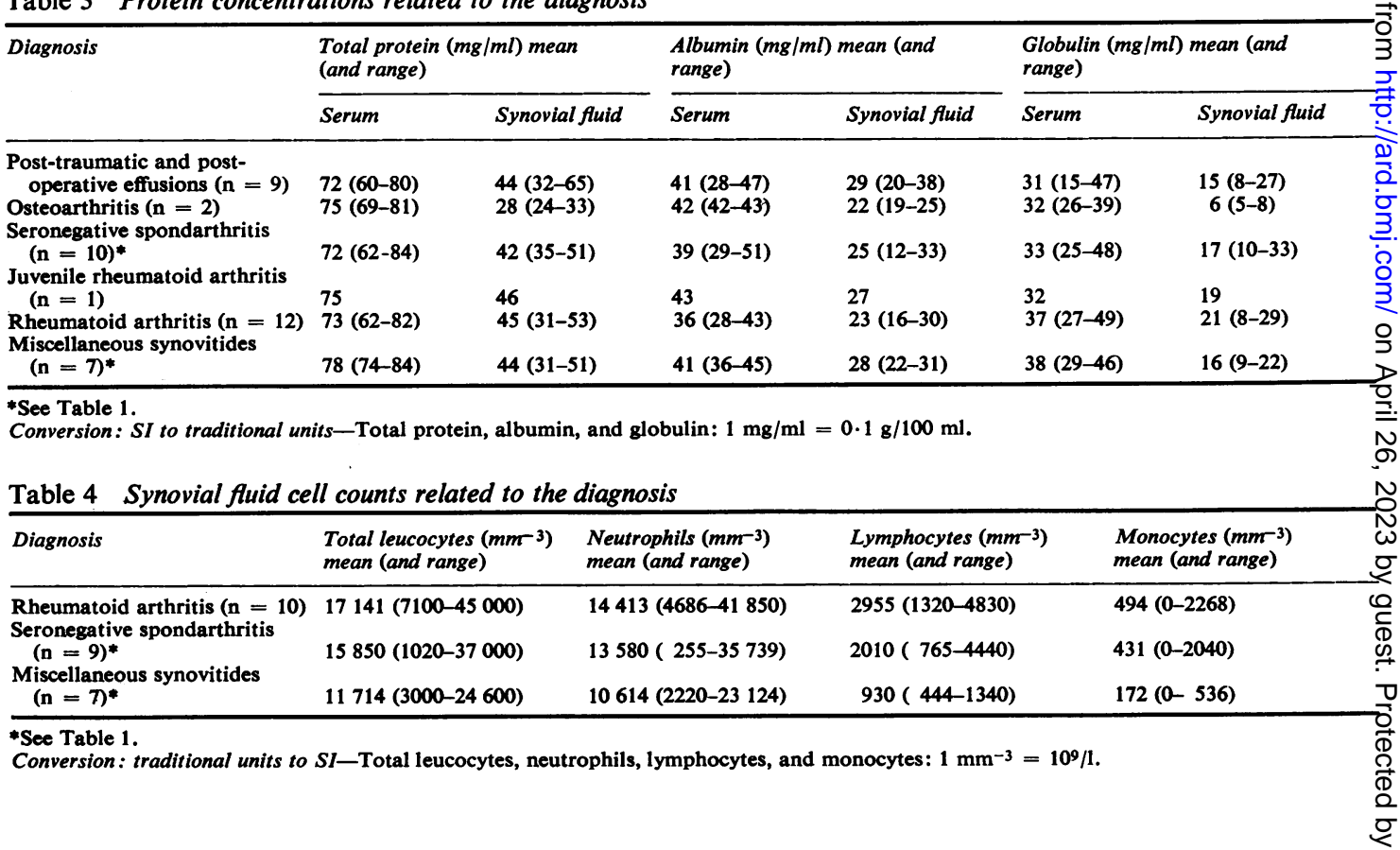


EVALUATION OF INHIBITORS IN

SYNOVIAL FLUID

\section{${ }^{3} \mathrm{H}$-thymidine}

When synovial fluids giving valid somatomedin assays from 1 patient with arthritis associated with Reiter's disease and from 1 patient with arthritis associated with psoriasis were each mixed in varying proportions with SRS, the potency ratio for the mixture in terms of SRS approximated the value that could be predicted by adding the expected potency ratios for the 2 componant fluids (Table 5). The potency ratio of SRS is, by definition, 1.00 and the expected potency ratio of $50 \%$ SRS in terms of SRS (ie $50 \%$ SRS/SRS) is 0.50 . The measured potency ratio of SF/SRS was 0.33 , so the expected potency ratio of $50 \% \mathrm{SF} / \mathrm{SRS}$ is 0.16 (ie, $50 \%$ of 0.33 ). The predicted potency ratio for a mixture of $50 \%$ SRS + $50 \% \mathrm{SF}$ in terms of SRS is therefore $0.50+0 \cdot 16=$ 0.66 ; the measured potency ratio was 0.65 . Similarly, the predicted potency ratio for $25 \%$ SRS $+75 \%$ SF is $0.25+0.25=0.50$ and the measured potency ratio was $0 \cdot 51$. It seems likely then that the SRS and the synovial fluid were each contributing to the somatomedin activity in the mixture. However, the potency ratio for $75 \% \mathrm{SRS}+25 \% \mathrm{SF}$ was lower than that predicted; the reason for this is not known.

When the synovial fluids which evoked decreasing isotopic uptake with increasing concentration from 1 patient with rheumatoid arthritis and from 1 patient with seronegative oligoarthritis were each similarly mixed with SRS the resultant mixtures produced dose response curves that were not parallel with the SRS over the whole dilution range (Fig. 3). Parallelism was obtained over the lower concentrations of the mixtures, with a level of isotopic uptake that could be expected from the SRS alone. At the higher concentrations, however, there was less isotopic uptake than could be predicted from the SRS component alone, thus confirming the presence

Table $5{ }^{3} \mathrm{H}$-thymidine incorporation. The effect of mixing synovial fluid $(S F)$ from a patient with arthritis associated with Reiter's disease with the standard reference serum (SRS)

\begin{tabular}{lll}
\hline Fluids compared & $\begin{array}{l}\text { Measured potency } \\
\text { ratio (and 95\% } \\
\text { fiducial limits) }\end{array}$ & $\begin{array}{l}\text { Predicted potency } \\
\text { ratio }\end{array}$ \\
\hline SF/SRS & $0.33(0.19-0.52)$ & - \\
$75 \%$ SRS $+25 \%$ & $0.54(0.36-0.78)$ & $0.75+0.08=0.83$ \\
$\begin{array}{l}\text { SF/SRS } \\
\text { 50\% SRS + 50\% }\end{array}$ & $0.65(0.39-1.07)$ & $0.50+0.16=0.66$ \\
$\begin{array}{l}\text { SF/SRS } \\
\text { S5 SRS + 75\% } \\
\text { SF/SRS }\end{array}$ & $0.51(0.33-0.74)$ & $0.25+0.25=0.50$ \\
\hline
\end{tabular}

of inhibitors to somatomedin activity in these fluids. The degree of inhibition of SRS somatomedin activity increased with increasing proportions of these synovial fluids. Moreover, the dose response curve for ${ }^{3} \mathrm{H}$-thymidine incorporation obtained with the mixture of $25 \%$ SRS $+75 \%$ synovial fluid was similar to the response obtained with 2 pathological synovial fluids (Fig. 2D).

\section{${ }^{35} S$-sulphate}

The results obtained for ${ }^{35} \mathrm{~S}$-sulphate incorporation resembled those for ${ }^{3} \mathrm{H}$-thymidine uptake although the precision was lower.

\section{EVALUATION OF THE INFLUENCE OF HYALURONIC ACID ON THE SOMATOMEDIN ACTIVITY IN NORMAL SERUM}

\section{${ }^{3} \mathrm{H}$-thymidine incorporation}

The addition of hyaluronic acid to serum had an inhibitory effect on DNA synthesis which was dosedependent (Fig. 4). At the lower concentrations of hyaluronic acid $(0 \cdot 25,0 \cdot 5$, and $1 \cdot 0 \mathrm{mg} / \mathrm{ml})$ the serum somatomedin activity was reduced, but the responses were parallel with those for the serum alone. At $2.0 \mathrm{mg} / \mathrm{ml}$ hyaluronic acid the responses were not parallel with those for the serum alone in 2 of the 3 experiments; and at $4.0 \mathrm{mg} / \mathrm{ml}$ hyaluronic acid the responses were not parallel in any of the 3 experiments.

\section{${ }^{35} S$-sulphate incorporation}

The dose response curves for serum supplemented with hyaluronic acid were in all cases parallel with the response curves for the serum alone. There was no significant difference between the uptake of ${ }^{35} \mathrm{~S}$-sulphate for the 5 concentrations of hyaluronic acid examined in any of the 3 experiments. The potency ratios for all the hyaluronic acid concentrations in the 3 experiments were therefore combined, and the weighted mean potency ratio (Finney, 1964) of serum supplemented with hyaluronic acid in terms of serum alone was 0.91 ( $95 \%$ fiducial limits $0 \cdot 80$ to $1 \cdot 04$ ).

\section{Discussion}

SERA

The somatomedin potency ratio of adult human serum may be expected to approximate to $1 \cdot 0$, that is to have a similar somatomedin activity to the SRS (a pool of normal human serum). The serum somatomedin potency ratios for the patients in this study were generally lower than $1 \cdot 0$; and there was a significant inverse correlation between the serum somatomedin potency ratio and the age of the 


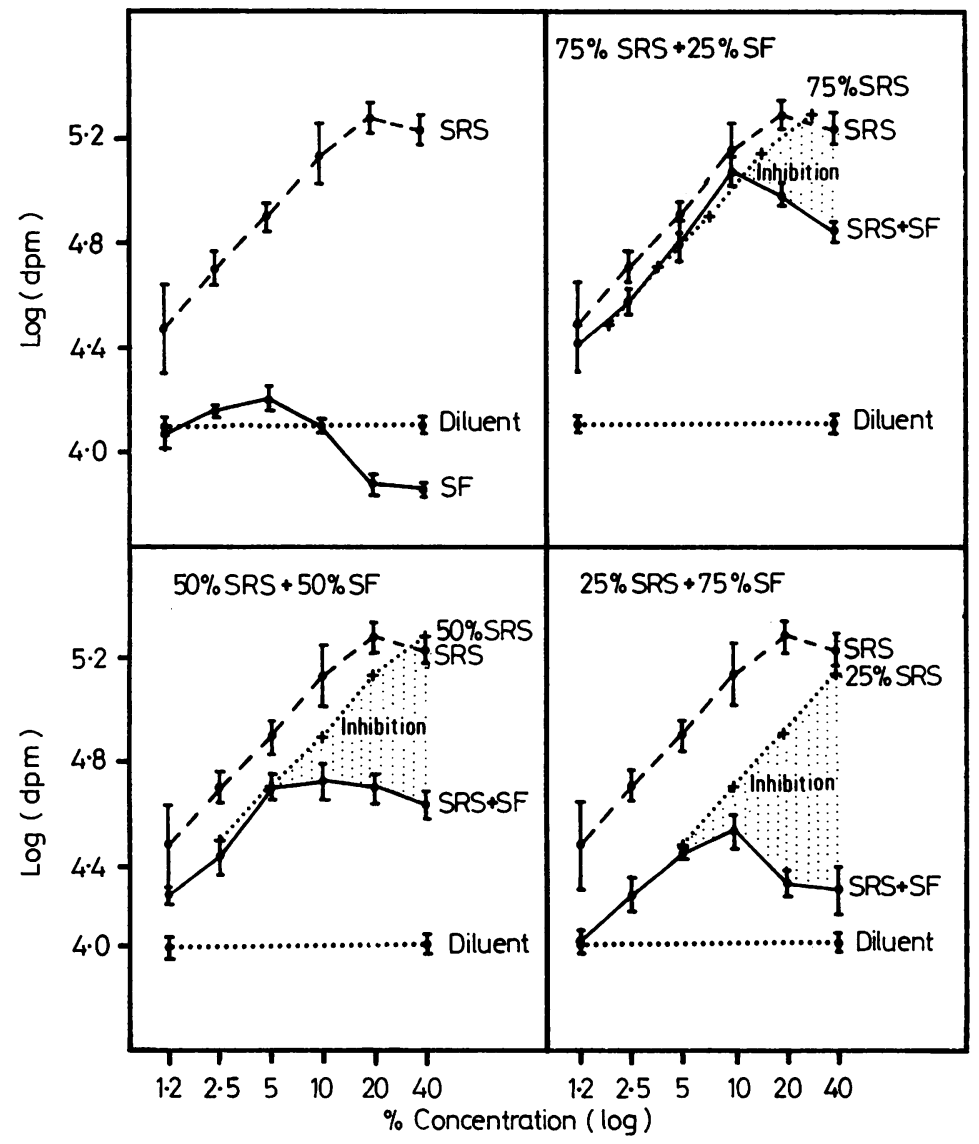

Fig. 3 The effect of mixing synovial fluid $(S F)$ from a 54 year old female patient with rheumatoid arthritis with the standard reference serum (SRS) upon the uptake of ${ }^{3} \mathrm{H}$-thymidine (log dpm) into porcine costal cartilage as a function of the log of the concentrations of the fluids. The dotted line $(+\ldots+)$ shows the predicted isotopic uptake for the $S R S$ component of the mixture to be compared with the measured isotopic uptake of the mixture. The stippled areas show the inhibition of isotopic uptake by the synovial fluid.

patient. Serum somatomedin activity in children has been widely reported and in normal children it has been shown to be very low at birth and to increase with age, adult levels gradually being reached after the age of about 10 years (Van den Brande and Du Caju, 1974b; Tato et al., 1975; Burwell et al., 1977). There is little reported work, however, on serum somatomedin levels in ageing adults. It is possible that age, injury, disease, and/or drug therapy may affect somatomedin generation and/or activity.

\section{SYNOVIAL FLUIDS}

The synovial fluids from patients with post-traumatic and post-operative effusions, osteoarthritis, and seronegative spondarthritis produced dose response curves for ${ }^{3} \mathrm{H}$-thymidine incorporation that were, in general, parallel with the patient's own serum and the SRS. Hence the factor(s) in the synovial fluid from the patients with these disorders and diseases which influenced the metabolism of cartilage is likely to be somatomedin(s). The somatomedin activity was always lower in the synovial fluid thare in serum from the same patient. This is probably because serum somatomedin is bound to a proteing of molecular weight $\geqslant 50000$ (Van Wyk et al., 1971 \% Hintz et al., 1974; Van Wyk et al., 1974; Yalow et al. 1975) and protein concentrations were lower in synovial fluid than in serum (Table 4). It also seems likely that the hyaluronic acid in synovial fluid mayo reduce the apparent somatomedin activity.

None of the synovial fluids from patients wit rheumatoid arthritis produced a dose response line for ${ }^{3} \mathrm{H}$-thymidine incorporation that was paralle with the patient's own serum or with the SRS. The dose response curves for some of these synoviand fluids had a significant regression, others had ab insignificant regression and the majority had significant negative regression. These different slopes for the dose response curves were found to be repros ducible when 9 of the synovial fluids were reassayed 5 but as yet the synovial fluid from only 1 patient wite -rheumatoid arthritis has been aspirated and assaye 


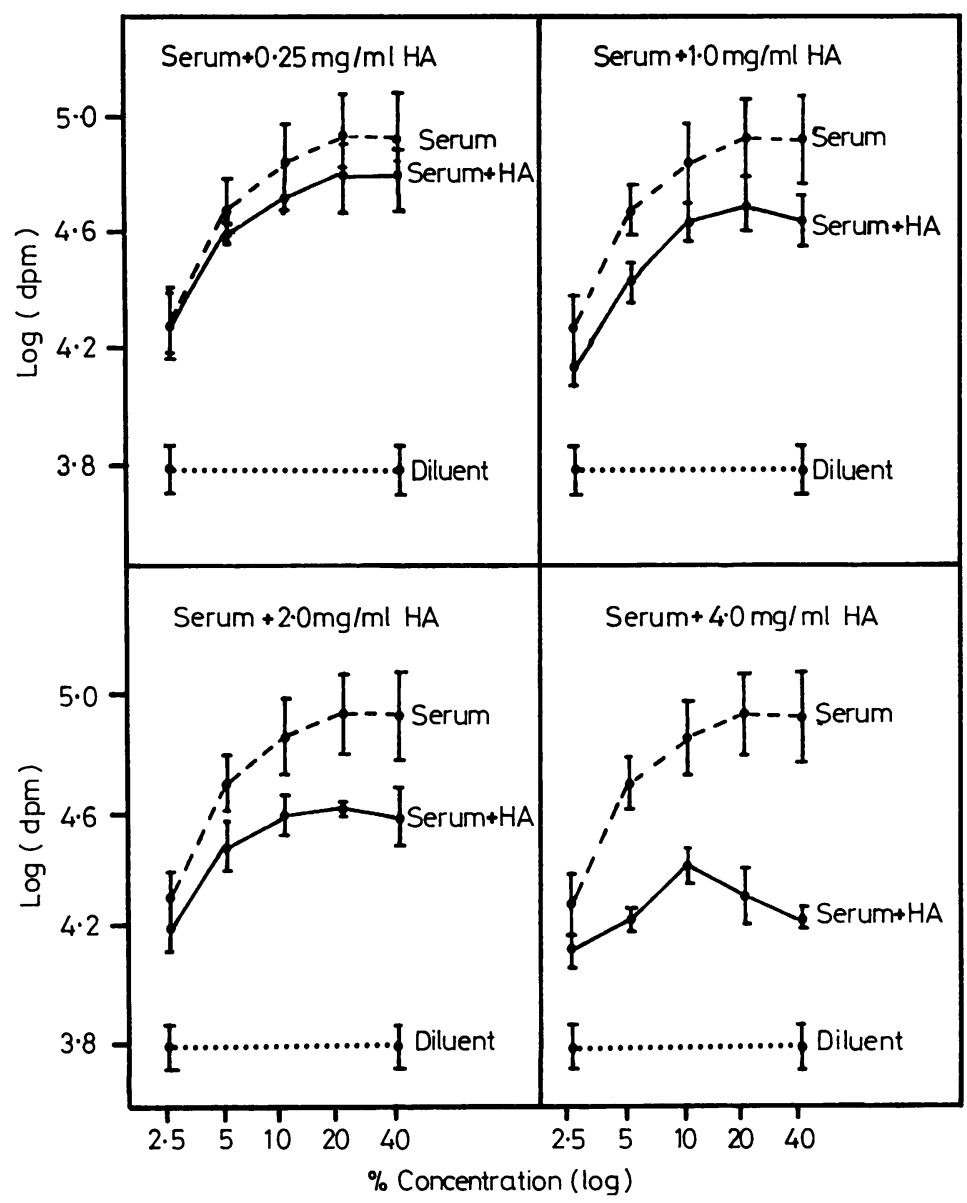

Fig. 4 The effect of adding hyaluronic acid $(H A)$ to normal serum upon the uptake of ${ }^{3} \mathrm{H}$-thymidine (log dpm) into porcine costal cartilage. (The effect of adding $0.5 \mathrm{mg} / \mathrm{ml}$ hyaluronic acid to serum is not shown.) on 2 occasions. The different responses may be caused by the presence of different factors in the synovial fluids or by varying concentrations of the same factor. Since the clinical features of rheumatoid arthritis may change with time, synovial fluid samples taken on different occasions may not give identical results. Further work is required to clarify this aspect.

In ox fluids it has been shown that there is a significant correlation between the total protein and albumin content of serum and synovial fluid and the somatomedin activity (Coates et al., 1977). The serum somatomedin levels were equivalent in both rheumatoid and non-rheumatoid patients; and the protein concentrations were similar in each of the serum and the synovial fluid of rheumatoid and nonrheumatoid patients. Somatomedin levels in synovial fluid would therefore be expected to be similar in all the patients unless the passage of protein-bound somatomedin across the synovial membrane was selectively restricted in some of them. This may result, for example, from the effects of the disease itself, drugs, ageing, or the interaction of these factors. If somatomedin does enter a rheumatoid joint, then the synovial fluid somatomedin assays may have been invalid due to the degradation of somatomedin within the joint and/or from the presence of specific or non-specific inhibitors to somatomedin activity.

The presence of a factor(s) in synovial fluid from several patients with rheumatoid arthritis and from some patients with miscellaneous synovitides that was capable of inhibiting the basal level of DNA synthesis was suggested by the lower level of isotopic uptake obtained with the higher concentrations of certain of these fluids than with the diluent (an amino acid solution). The ability of this factor(s) to inhibit somatomedin-stimulated DNA synthesis was demonstrated when synovial fluid from 1 patient with rheumatoid arthritis and from 1 patient 
with seronegative oligoarthritis were each mixed with SRS; the ability of SRS-somatomedin to stimulate DNA synthesis was reduced at the higher concentrations of these mixtures.

Because of the different bioassay responses of the serum and the synovial fluid from patients with rheumatoid arthritis, any inhibitors in the synovial fluid must either accumulate in the joint or be produced locally by the articular surface and/or the synovial cells. Possible factors that may contribute to the inhibition include: hyaluronic acid and/or its breakdown products: lysosomal enzymes; rheumatoid factor and other agents associated with the immune response; cortisol; and drugs. The addition of hyaluronic acid to normal serum was found to have a dose-dependent inhibitory effect on DNA synthesis in cartilage. Serum supplemented with $4.0 \mathrm{mg} / \mathrm{ml}$ hyaluronic acid gave invalid somatomedin assays and the dose response curves were similar to those obtained with some pathological synovial fluids. Proteogylcan synthesis was slightly reduced by the addition of hyaluronic acid to serum, but valid somatomedin assays were obtained for all the concentrations of hyaluronic acid tested. It must be emphasised, however, that the addition of hyaluronic acid to serum does not create the composition of synovial fluid.

Hyaluronic acid has been reported to decrease proteoglycan synthesis in cultures of chondrocytes obtained from both adult (Wiebkin et al., 1975) and embryonic cartilage (Toole, 1973; Solursh et al., 1974; Handley and Lowther, 1976). DNA synthesis in chick embryo chondrocytes was, however, found to be unaffected by hyaluronic acid (Toole, 1973; Solursh et al., 1974).

The possibility that the inhibitory effect of rheumatoid synovial fluid upon DNA synthesis in porcine costal cartilage, which we have found, was due to the concentration of hyaluronic acid in these fluids seems unlikely since hyaluronic acid is present in lower concentrations in rheumatoid synovial fluid than it is in normal human synovial fluid (Hamerman and Schuster, 1958a, 1958b; Decker et al., 1959). Hyaluronic acid may, however, still contribute to the inhibitory properties of the rheumatoid synovial fluid in the following ways. Firstly, in rheumatoid synovial fluid, hyaluronic acid has a decreased molecular weight due to a reduced polymer length (Barker et al., 1963; Seppälä, 1964; Balazs et al., 1967); hence hyaluronic acid in rheumatoid synovial fluid may have a different effect on cartilage metabolism than hyaluronic acid in normal synovial fluid. Secondly, because the enzymic breakdown of hyaluronic acid has been shown to produce oligosaccharides which are inhibitory to proteoglycan synthesis in cartilage
(Toole, 1973; Solursh et al., 1974; Wiebkin et al. $\frac{\vec{\Phi}}{\frac{\pi}{\frac{\pi}{2}}}$ 1975), it is possible that oligosaccharides of hy aluronic acid are involved in the inhibitory effect of. rheumatoid synovial fluid.

There is evidence that immune mechanism $\overrightarrow{\vec{F}_{\text {f }}}$ participate in the pathogenesis of rheumatoid arthritis (Zvaifler, 1973; Maini, 1977). Any of the factors involved in the immune response that ar $\overline{-}$. present at different concentrations in synovial flui and serum may contribute to the inhibitory proper $\overline{\bar{\alpha}}$ ties of rheumatoid synovial fluids revealed by the porcine costal cartilage bioassay. It seems unlikel $\vec{p}$ that rheumatoid factor itself is responsible for the inhibition since it is usually present at similafs concentrations in synovial fluid and in serume (Huskisson et al., 1971; Cracchiolo and Barnet? 1972; MacSween et al., 1972). It may, however, bẹ indirectly involved since serum complexes of IgGi rheumatoid factor differ from those found in joint fluids (Zvaifler, 1973). In rheumatoid arthritis the damage to articular cartilage is thought to be medi? ated by lysosomal enzymes (Dingle, 1962; Weiss $\vec{s}$ mann, 1966; Page Thomas, 1969). Biochemicas studies have shown that the activities of manye enzymes are raised in synovial fluid from patients with rheumatoid arthritis, but are normal in synokjate fluid from patients with osteoarthritis (Caygill a Pitkeathly, 1966; Jasani et al., 1969; Pruzanski et ब․․응 1970).

Cortisol, indomethacin, and ibuprofen have $\stackrel{a}{a}$ 号 been reported to reduce proteoglycan synthesis ing cartilage (Van den Brande et al., 1975; McKenzi⿺辶⿸ et al., 1976). The additions of 0.5 to $9.0 \mu \mathrm{g} / \mathrm{ml}$ of indomethacin and of 6.25 to $50 \mu \mathrm{g} / \mathrm{ml}$ of sodium ibuprofen to serum were, however, found to have little effect on the somatomedin activity (Coates 1977). Cortisol estimations revealed higher levels in the sera than in the synovial fluids, with simila 5 concentrations in each of these fluids from alb patients. It is therefore unlikely that these compounds were responsible for the inhibitory properties of the rheumatoid synovial fluids. We are currently attempting to identify the inhibitory factor(s).

The possible use of the bioassay to categorise patients with synovitis is currently being evaluatedo

Possible relevance of the findings to rheumatoi $\mathbb{\Phi}^{\circ}$ arthritis

The effect of pathological synovial fluid has so fatt been determined only on porcine costal cartilage and the results may not be directly applicable to adulf human articular cartilage. It has, however, beer帕 shown that chondrocytes dissociated from rabbif? articular cartilage respond to somatomedin in normaib human serum (Binet et al., 1975), and to somatomediñ. produced by the perfusion of growth hormone 
through the liver (Ash and Francis, 1975). Since human adult articular cartilage is probably dependent on synovial fluid as its sole source of nutrients (Hodge and McKibbin, 1969), somatomedin(s) in synovial fluid may be expected to play a role in the metabolism of this tissue.

In rheumatoid articular cartilage large numbers of degenerating, dead, and disintegrating cells have been reported (Mitchell and Shepard, 1970). If the inhibitor(s) of DNA metabolism in rheumatoid synovial fluid revealed by the porcine costal cartilage bioassay is also active against human articular cartilage, it may hinder any attempted replacement of the necrotic cells. The inhibition of proteoglycan synthesis could lead to matrix proteoglycan depletion, thus predisposing the cartilage collagen framework to mechanically-induced damage. In addition, depletion of the cartilage matrix may allow high molecular weight components, such as immunoglobulins, to penetrate the matrix and gain access to the chondrocytes (Poole et al., 1973).

It has been shown that articular cartilage from patients with rheumatoid arthritis incubated in a synthetic medium synthesises more proteoglycan where the matrix has been eroded than in the noneroded cartilage (Jacoby and Jayson, 1976). Our results question whether this repair revealed by using a synthetic medium in vitro would proceed in the presence of rheumatoid synovial fluid. The influence of both normal and pathological synovial fluid on the metabolism of normal and pathological articular cartilage needs further study.

We are indebted to the National Fund for Research into Crippling Diseases for the finance to undertake this work and Professor R. E. Coupland for facilities. We thank Mr J. P. Jackson, FRCS and and Professor W. Waugh for samples of synovial fluid.

\section{References}

Ash, P., and Francis, M. J. O. (1975). Response of isolated rabbit articular and epiphyseal chondrocytes to rat liver somatomedin. Journal of Endocrinology, 66, 71-78.

Balazs, E. A., Watson, D., Duff, I. F., and Roseman, S. (1967). Hyaluronic acid in synovial fluid. I. Molecular parameters of hyaluronic acid in normal and arthritic human fluids. Arthritis and Rheumatism, 10, 357-376.

Barker, S. A., Bayyuk, S. H. I., Brimacombe, J. S., Hawkins, C. F., and Stacey, M. (1963). Fingerprinting the hyaluronic acid component of normal and pathological synovial fluids. Clinica Chimica Acta, 8, 902-909.

Binet, E., Schlumberger, A., Fournier, F., Chaussain, J.-L., and Job, J.-C. (1975). Sensibilité des chondrocytes articulaires de lapin isolés à l'activite somatomédine de sérum humain. Comptes Rendus Hebdomadaires des Séances de l'Académie des Sciences; D: Sciences Naturelles (Paris), 280, 1713-1716.
Burwell, R. G., Dangerfield, P. H., and Vernon, C. L. (1977). Anthropometry and scoliosis. Scoliosis, a Fifth Symposium, pp. 123-163. Ed. by P. A. Zorab. Academic Press, London.

Caygill, J. C., and Pitkeathly, D. A. (1966). A study of $\beta$ acetylglucosaminase and acid phosphatase in pathological joint fluids. Annals of the Rheumatic Diseases, 25, 137-144.

Coates, C. L. (1977). A Study of the Influence of Synovial Fluid and Serum upon Cartilage Metabolism with Particular Reference to the Rheumatic Diseases. Thesis, University of Nottingham.

Coates, C. L., Burwell, R. G., Buttery, P. J., Walker, G., and Woodward, P. M. (1977). Somatomedin activity in synovial fluid. Annals of the Rheumatic Diseases, 36, 50-55.

Cracchiolo, A., and Barnett, E. V. (1972). The role of immunological tests in routine synovial fluid analysis. Journal of Bone and Joint Surgery, 54A, 828-840.

Decker, B., McGuckin, W. F., and McKenzie, B. F. (1959). Concentration of hyaluronic acid in synovial fluid. Clinical Chemistry, 5, 465-469.

Dingle, J. T. (1962). Lysosomal enzymes and the degradation of cartilage matrix. Proceedings of the Royal Society of Medicine, 55, 109-111.

Dittmer, D. S. (1961). Blood and Other Body Fluids, p. 329. Federation of American Societies for Experimental Biology, Washington, DC.

Finney, D. J. (1964). Statistical Method in Biological Assay. 2nd ed., pp. 99-138. Griffin, London.

Hamerman, D., and Schuster, H. (1958a). Hyaluronate in normal synovial fluid. Journal of Clinical Investigation, 37, $57-64$.

Hamerman, D., and Schuster, H. (1958b). Synovial fluid hyaluronate in rheumatoid arthritis. Arthritis and Rheumatism, 1, 523-531.

Handley, C. J., and Lowther, D. A. (1976). Inhibition of proteoglycan biosynthesis by hyaluronic acid in chondrocytes in cell culture. Biochimica et Biophysica Acta, 444, 69-74.

Hintz, R. L., Orsini, E. M., and Van Camp, M. G. (1974). Evidence for a somatomedin binding protein in plasma. Endocrinology (Supplement), 94, A71.

Hodge, J. A., and McKibbin, B. (1969). The nutrition of mature and immature cartilage in rabbits. Journal of Bone and Joint Surgery, 51B, 140-147.

Huskisson, E. C., Dudley Hart, F., and Lacey, B. W. (1971). Synovial fluid Waaler-Rose and latex tests. Annals of the Rheumatic Diseases, 30, 67-71.

Jacoby, R. K., and Jayson, M. I. V. (1976). Synthesis of glycosaminoglycan in adult human articular cartilage in organ culture from patients with rheumatoid arthritis. Annals of the Rheumatic Diseases, 35, 32-36.

Jasani, M. K., Katori, M., and Lewis, G. P. (1969). Intracellular enzymes and kinin enzymes in synovial fluid in joint diseases. Annals of the Rheumatic Diseases, 28, 497-511.

McKenzie, L. S., Horsburgh, B. A., Ghosh, P., and Taylor, T. K. F. (1976). Effect of anti-inflammatory drugs on sulphated glycosaminoglycan synthesis in aged human articular cartilage. Annals of the Rheumatic Diseases, 35, 487-497.

MacSween, R. N. M., Dalakos, T. K., Jasani, M. K., and Buchanan, W. W. (1972). Rheumatoid factor in serum and synovial fluid. Scandinavian Journal of Rheumatology, 1, 177-180.

Maini, R. N. (1977). Immunology of the Rheumatic Diseases. Aspects of Autoimmunity. Edward Arnold, London.

Mitchell, N., and Shepard, N. (1970). The ultrastructure of articular cartilage in rheumatoid arthritis. Journal of Bone and Joint Surgery, 52A, 1405-1423. 
Page Thomas, D. P. (1969). Lysosomal enzymes in experimental and rheumatoid arthritis. Lysosomes in Biology and Pathology, Vol. 2, pp. 87-110. Ed. by J. T. Dingle and H. B. Fell. North-Holland Publishing Company, Amsterdam.

Poole, A. R., Barratt, M. E. J., and Fell, H. B. (1973). The role of soft connective tissue in the breakdown of pig articular cartilage cultivated in the presence of complementsufficient antiserum to pig erythrocytes. II. Distribution of immunoglobulin G (IgG). International Archives of Allergy and Applied Immunology, 44, 469-488.

Pruzanski, W., Saito, S., and Ogryzlo, M. A. (1970). The significance of lysozyme (muramidase) in rheumatoid arthritis. I. Levels in serum and synovial fluid. Arthritis and Rheumatism, 13, 389-399.

Ropes, M. W., Bennett, G. A., Cobb, S., Jacox, R., and Jessar, R. A. (1959). Diagnostic criteria for rheumatoid arthritis. 1958 Revision. Annals of the Rheumatic Diseases, 18, 49-51.

Seppälä, P. (1964). Synovial fluid in rheumatoid arthritis. Scandinavian Journal of Clinical and Laboratory Investigation, 16, Supplement 79.

Solursh, M., Vaerewyck, S. A., and Reiter, R. S. (1974). Depression by hyaluronic acid of glycosaminoglycan synthesis by cultured chick embryo chondrocytes. Developmental Biology, 41, 233-244.

Tato, L., Du Caju, M. V. L., Prévôt, C., and Rappaport, R. (1975). Early variations of plasma somatomedin activity in the newborn. Journal of Clinical Endocrinology and Metabolism, 40, 534-536.

Toole, B. P. (1973). Hyaluronate and hyaluronidase in morphogenesis and differentiation. American Zoologist, 13, 1061-1065.

Van den Brande, J. L., and Du Caju, M. V. L. (1974a). An improved technique for measuring somatomedin activity in vitro. Acta Endocrinologica, 75, 233-242.
Van den Brande, J. L., and Du Caju, M. V. L. (1974b 9 Plasma somatomedin activity in children with grow disturbances. Advances in Human Growth Hormow Research, pp. 98-115. Ed. by S. Raiti, DHEW Publicatiōi No. (NIH) 74-612.

Van den Brande, J. L., Van Buul, S., Heinrich, U., V $\overrightarrow{\overrightarrow{\text { an }}}$ Roon, F., Zurcher, T., and Van Steirtegem, A. C. (1975). Further observations on plasma somatomedin activity children. Advances in Metabolic Disorders, 8, 171-181.

Van Wyk, J. J., Hall, K., Van den Brande, J. L., and Weave户, R. P. (1971). Further purification and characterisation \&f sulphation factor and thymidine factor from acromegabic plasma. Journal of Clinical Endocrinology and Metabolisfh, 32, 389-403.

Van Wyk, J. J., Underwood, L. E., Hintz, R. L., Clemmonis D. R., Voina, S. J., and Weaver, R. P. (1974). The somat $\vec{\Theta}$ medins: A family of insulinlike hormones under grow hormone control. Recent Progress in Hormone Research, 30, 259-318.

Weissmann, G. (1966). Lysosomes and joint disease. Arthri and Rheumatism, 9, 834-840.

Wiebkin, O. W., Hardingham, T. E., and Muir, H. (1975) The interaction of proteoglycans and hyaluronic acid an the effect of hyaluronic acid on proteoglycan synthesis by chondrocytes of adult cartilage. Dynamics of Connective Tissue Macromolecules, pp. 81-104. Ed. by P. M. Є. Burleigh and A. R. Poole. North-Holland Publishi跔 Company, Amsterdam.

Yalow, R. S., Hall, K., and Luft, R. (1975). Radioimmuntsassay of somatomedin B. Application to clinical and physiological studies. Journal of Clinical Investigation 127-137.

Zvaifler, N. J. (1973). The immunopathology of toint inflammation in rheumatoid arthritis. Advance Immunology, 16, 265-336. 